\title{
Practical Shooter Comes to Downers Grove George Starbuck
}

They've took my Mach-10 Special.

They've took Dad's Remingtons.

When they get Bubba's, only

The in-laws will have guns.

Saturday night's a longshot

Contraption as it is.

A man without a Magnum's

A piece of agribiz.

He might as well push daisies

And model for a wreath

And pick a granite afghan

To cuddle up beneath.

You've seen the streets of Berwyn

In the county name of Cook.

We're talkin' cold survival.

We're talkin' donnybrook.

What if a drunk accosts you

And mouths an ethnic slur?

What if your wife takes refuge

And you catch up with her?

It's people that kill people,

An' people's bustin' west

Out of the inner suburbs

Like they was air-expressed.

It isn't just lost hardware

And that they got no right.

It's the humiliation.

You take last Tuesday night: 
There in my bed, defenseless,

Woke up at three a.m.

And up the stair come footsteps.

It had to have been them.

I was a sitting target

Disarmed by liberals.

Ransacked my bedside table

And all I found was pills.

You see the situation?

You see the price of it?

A thousand drowsing suburbs

Just waitin' to be hit.

What if it had been baddies

And not Great Aunt Irene?

What if the one split-second

When they're behind the screen

And I'm where I can zero

Their shadow-image in

And they can't see who's pumpin'

Their bellies full of tin

Goes by, in dumb frustration,

While I'm still gropin' for

The family peacekeeper

That I ain't got no more?

I tell you there'd be henchmen

Emboldened by my death

Rampagin' into Downers

Before you get your breath.

(It takes a heap o' henchmen

To give them hophead hoods

The yellowdog bravado

To raid the neighborhoods. 
It takes a heap o' henchmen

In winrows up the stairs

Now-and-then, to remind 'em

The country just ain't theirs.)

You think about your houses.

You think about your wives.

You think about the access

To ten-inch carving knives

And Lizzie Borden hat pins And side arms of their own

Among the rougher classes.

Next time you hear the phone

Click off, because you answered

In your best Eastwood voice,

You think about it, Mister.

You only got one choice.

Stonewall 'em, like the heroes

And braves of long ago.

A man don't need a castle

To have an Alamo. 